\title{
湾曲型空気圧ソフトアクチュエータの開発と応用*
}

\author{
篠 原 隆*1, 堂田 周治郎*2, 松下 尚 史*2

\section{Development of a Pneumatic Bending Soft-Actuator and its Application}

Takashi SHINOHARA, Shujiro DOHTA*3 and Hisashi MATSUSHITA

${ }^{* 3}$ Department of Intelligent Mechanical Engineering, Okayama University of Science, 1-1 Ridai-cho, Okayama-shi, Okayama, 700-0005 Japan

\begin{abstract}
Recently, we need a human friendly robot which can provide human several services. When such a human friendly robot interacts directly with human, it requires flexibility, safety and so on. In order to realize such a flexibility, there is a way to utilize a flexible material and air compressibility. Therefore, it is considered that the pneumatic soft actuator with passive compliance is useful. The purpose of our study is to develop the pneumatic soft actuator in order to realize the robot with flexibility. We have developed a pneumatic bending soft actuator which is made of silicone rubber. We call it soft gripper. The soft gripper can be applied to a finger of robot hand, artificial hand and so on. In this paper, first, the structure, operation, principle and fundamental characteristics of soft gripper are shown. Next, the proposed analytical model of soft gripper is described and it is confirmed that the proposed model is useful for designing the gripper by comparing the calculated results with the experimental results. Finally, as an application of the soft actuator, a rubber robot hand with grippers is introduced.
\end{abstract}

Key Words : Soft Actuator, Soft Gripper, Rubber Finger, Pneumatic Robot Hand, Human Friendly Robot

\section{1. 粕 吾}

近年, 日本の高齢化社会に伴い, 医療・福祉の分 野では人の支援・介護が行えるロボットやロボットハ ンドの開発導入が望まれている. このような人間共存 型ロボットツは，人間と直接触れ合う環境において使 用されるので，柔軟性や安全性といった人間親和性が 要求されるき. 柔らかいロボットの実現には, 硬いメ カニズムに各種センサを取り付けてコンプライアンス 制御はどを行う方法がある. 一方, 連続的な変形が 可能であることやシステムが簡単になることから柔ら かい材料を用いる方法㵽ある.これには，繊維強化 ゴム製のフレキシブルマイクロアクチュエータ (FMA) 济，マッキベン型ゴム人工筋，シリコーンゴ ムボールを関節部に設置した摇動型アクチュエータな ど, 駆動源が空気在であり受動的柔軟性を備えた空気 圧ソフトアクチュエータのの゙ある。

著者らは，ロボットハンドの指や義手などに応用で きる構造が簡単な湾曲型空気圧ソフトアクチュエータ

\footnotetext{
* 原稿受付 2005 年 1 月 19 日.

*1 正員, 岡山理科大学大学院工学研究科( 700-0005 岡山市 理大町 1-1).

*2 正員, 岡山理科大学工学部.

E-mail : dohta@are.ous.ac.jp
}

を開発した. これをソフトグリッパと呼ぶことにする. 本論文では, ソフトグリッパの構造, 特性, そして解 析モデルについて述べる. 本論文の構成は以下の通り である. 第 2 章でソフトグリッパの構造と動作原理, 基本特性について述べる. 第 3 章で用途別グリッパに ついて述へ，第 4 章でソフトグリッパの設計に役立て るための解析モデルを提案し, 実験結果との比較を行 いモデルの妥当性を示す. 第 5 章でソフトグリッパの 応用例として, 試作した人間型五指ハンドについて述 べ，最後に第 6 章で本論文の結論を述べる.

\section{2. 基本ソフトグリッパ}

$2 \cdot 1$ 權造と的作原理 基本的なソフトグリッ パの構造を図 1 に示す. ソフトグリッパはシリコーン ゴム（ダウコーニング社製 : シラスコン RTV-4168） 製であり，空気圧により駆動される，寸法は長さ $70 \mathrm{~mm}$, 幅 $12 \mathrm{~mm}$ の中空蒲鋅型になっており, 圧力室 断面形状は円形になっている. グリッパ内圧力室内壁 には中心軸に対して垂直に純綿水系（たくみ本舗社 製: 綿 $100 \%$, 直径 $0.8 \mathrm{~mm}$, 測量やタコあげ用) で $3 \mathrm{~mm}$ 間隔の瀻維拘束が施されている. 純綿水系を用 いる理由は, グリッパ形成時にシリコーンゴムをよく 


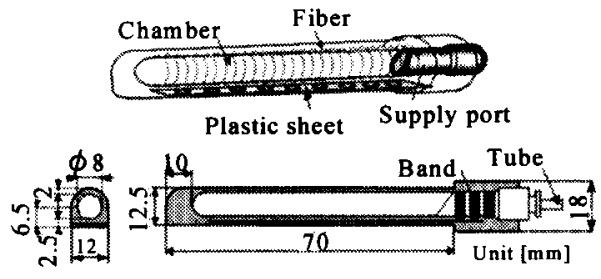

Fig. 1 Structure of soft gripper

含み，硬化後にズレや食い込みが少ないためである. また, グリッハ湾曲部内側には長さ $70 \mathrm{~mm}$, 幅 $7 \mathrm{~mm}$, 厚さ $0.5 \mathrm{~mm}$ の薄いプラスチックシートが埋め込まれ ており, シリコーンゴムとズレが生じないように直径 $3 \mathrm{~mm}$ の穴を複数個設けるとともに，プラスチックシ 一トの表面をサンドペーパで粗くする処理を施してい る.このプラスチックシートは, グリッパの曲がりや すさに影警を与えないように十分に薄く，伸びが発生 しないものが選ばれている. 動作原理は以下の通りで ある. グリッパの圧力室を加圷すると発生する湖長力 は, 綨維拘束により半径方向の伸びは抑えられ, 軸方 向の伸びになる. また, グリッパ下側の軸方向の纎稚 拘束と埋め込まれたプラスチックシートにより内側の 伸び抑えられるため, グリッパは内側に湾曲する. さらに、圧力室を大気に開放すると, ゴムの弾性力に よりグリッパは元の形状に戻る。このソフトグリッパ は三つの圧力室を有寸る FMA と原理的にはよく似て いるが圧力室が一つである点や片側軸方向を拘束して いる点が異なる.

2.2 基本特性 蟣稚拘束の間隔が $2 \mathrm{~mm}, 3 \mathrm{~mm}$, $4 \mathrm{~mm}, 5 \mathrm{~mm}, 6 \mathrm{~mm}$ の五種類のグリッパを製作し，緎 維拘束の間隔による発生力八の影獣を調べた. 図 2 に ソフトグリッパの供給圧力と発生力の関係を示す。こ

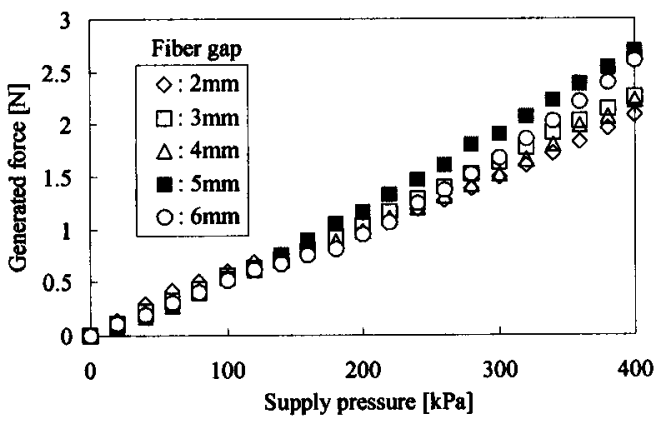

Fig. 2 Relation between supply pressure and generated force
れは，グリッハ根元を水平に固定し，デジタルフォー スグージに指先が水平に当たるように設置した. そし て, グリッパの圧力室を加圧した際, グリッバ指先が デジタルフォースゲージを押し付ける力を発生力とし て測定した，図より，各グリッパの発生力はほほ植線 的に増加していることがわかる. また，瀻維拘束間隔 の影刯を見ると間隔 $5 \mathrm{~mm}$ のグリッパが最も発生力が 高いことがわかる. 図 3 に供給圧力と湾曲変位の関釈 を示す.ここで湾曲変位とは，グリッハ外側（図 1 で は上側）表面に沿う変位量である，測定はグリッパを デジタルカメラで撮影しパソコンに取り込み変位量を 測定した. 図を見ると，供給圧力と湾曲変位の関係が， 拘束間隔 $2 \mathrm{~mm}$, 3mm 場合ほほ線形であるが, 間隔 $4 \mathrm{~mm}$ 以上の場合, やや非線形になることがわかる. 拘束間隔で比較すると，低い供給圧力では，間隔 $3 \mathrm{~mm}$ がよく湾曲しているが，高い供給圧力では，間 隔が大きいほうがよく湾曲していることがわかる．間 隔 $2 \mathrm{~mm}$ では瀻維拘束の間隔が密なため, 柔軟な湾曲 部分が少くなくなったり，拘束械維同士の干涉により 湾曲しにくくなったものと考えられる．また，拘束間 隔 4mm 以上では，低い供給圧力においては，間隔が 大きすぎるために半径方向の伸びが大きくなり，軸方 向一の湾曲外側の伸びが減少するため湾曲量が诚少す ると考えられる. 一方，高い供給圧力においては，半 径方向への影長力によっても，グリッパが湾曲するた めに湾曲量が増加したと考えられる. なお，拘束間隔 $4 \mathrm{~mm}$ 以上のグリッパは，織維強化が弱くなり， $300 \mathrm{kPa}$ 以上の空気を加圧するとグリッパが破裂しや すくなる．したがって, グリッパの㵶稚拘束間隔は $3 \mathrm{~mm}$ が最適であると判断した.

なお，試作したソフトグリッパの湾曲変位や発生 力にはゴムの遅延弾性などによるヒステリシスは見ら れなかった.

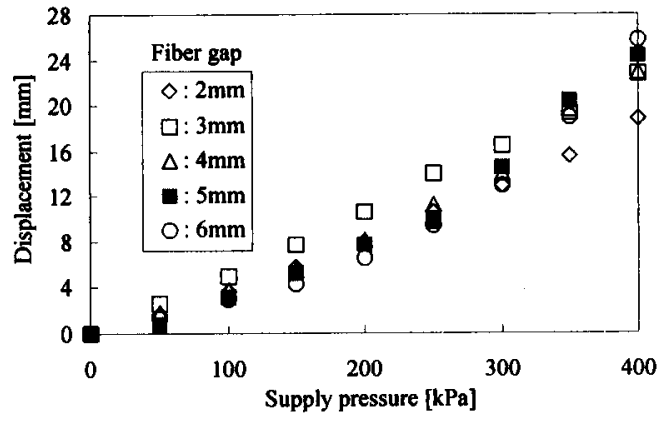

Fig. 3 Relation between supply pressure and bending displacement 


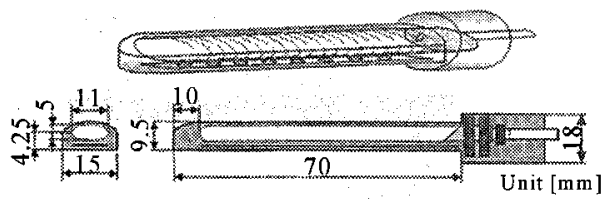

Fig. 4 Structure of flat-type gripper

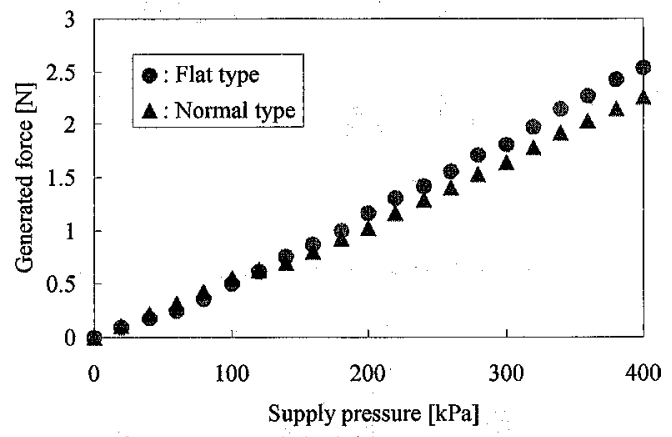

Fig. 5 Comparison of flattype and normal type grippers

\section{3. 用途別ソフトグリッパ}

3.1 平型グリッパ ソフトグリッパの発生力を増 寸ために，次章で述べるグリッパの解析モデルに基づ き，グリッパの圧力室断面形状を棈円形にした平型グ リッパを試作したここのグリッパの構造を図 4 に示寸. 式(17)から，発生力を大きくするには，グリッパ圧力 室断面積 $A$ と断面二次モーメシトI を大きくし，グ リッパ半径 $D_{g}$ とグリッパ自然長 $L_{01}$ を小さくすれば 良いことがわかる，断面積 $A$ や断面二次モーメント $I$ を大きくする方法怯，グリッパ自体が大きくなるので， グリッパ圧力室断面積 $A$ をほとんど変えずにグリッ パ半径 $D_{g}$ を減少させる.すなわち圧力室断面形状を 棈円形にすることを考えた．この変更により，Dg は $6.5 \mathrm{~mm}$ から $4.25 \mathrm{~mm}$ になる. 図 5 に平型グリッパと 基本グリッパの発生力の比較を示す：平型グリッパの 発生力は，供給圧力 $400 \mathrm{kPa}$ において基本グリッパに 比べ，12倍程度増加している． $D_{g}$ だけ考えると発生 力は 1.5 倍の増加が見込めるが，弾性係数 $K$ や断面 二次モ一メント I の減少と圧力室断面積の若干の減少 により発生力が 1.2 倍の増加に留まっていると考えら れる。

$3 \cdot 2$ 二室型グリッパ 指の動作範囲を広げる ために，圧力室を二つにした二室型グリッパを試作し た.このグリッパの構造を図 6に示す. 図のように圧 力室を二備えており，それぞれの圧力室は別々に加 压することができる. 寸法は長さ $115 \mathrm{~mm}$ ，幅 $12 \mathrm{~mm}$

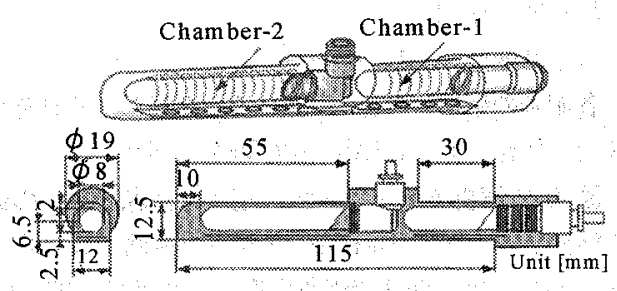

Fig. 6 Structure of 2-chamber type gripper

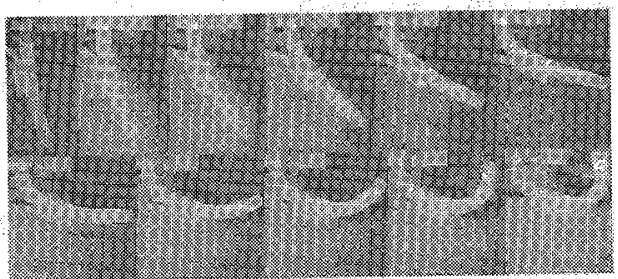

Fig. 7 Bending motions of 2-chamber type gripper

で，人間型ハンドを構成した場合，右側の部分（第一 圧力室, 根元側) は長さ $30 \mathrm{~mm}$ で人間の中手指節関 節 に相当する. 左側の部分（第二圧力室，指先側） は長さ $55 \mathrm{~mm}$ で中節骨と末節骨に相当する。これは 人間の指は二関節であるが，人間の近位指節間関節と 遠位指節閒関節は連動して動くのので対と考えてい るからである.また，中閒部分は基節骨に相当する。

図 7 に 2 室型ソフトグリッパの湾曲状態を示す。この グリッパはさまざまな湾曲動作が可能であることが確 認できる.

\section{4. 解析モデル}

4.1 仮定と定式化 グリッパの発生力を計算 し，設計に役立てるために，二室型グリッパを例とし て，ソフトグリッパの解析モデルを提案する. 以下に 用いる記号をまとめて記す。

$A:$ 压力室断面積 $\mathrm{m}^{2}$

$D_{g}:$ グリッパ半径 (グリッパ底面から压力室の中 心軸までの距離) $\mathrm{m}$

$D_{R}:$ 湾曲時の曲率半径 $\mathrm{m}$

$E$ : 絴弾性係数 $\mathrm{N} / \mathrm{m}^{2}$

$H:$ 指先水平方向変位 $\mathrm{m}$

$I:$ 断面二次モーメント $\mathrm{m}^{4}$

$K:$ 弾性係数 $\mathrm{N} / \mathrm{m}$

$L_{C}:$ 中心軸湾曲変位

(圧力室中心軸に沿う変位量) $\mathrm{m}$

$L_{0}:$ 圧力室自然長 $\mathrm{m}$

$P:$ 供給圧力 $\mathrm{Pa}$ 
$Q$ : 発生力 $\mathrm{N}$

$\alpha$ : 湾曲角 $\mathrm{rad}$

各記号の添字 $1,2, m$ ，は要素を示し，それぞれ 第一圧力室, 第二圧力室, 中間部分を示寸.

図 8 に解析モデルを示寸，定式化に際し以下の仮 定を設ける.（1）加圧時のグリッパ湾曲角 $\alpha$ は小さ い.（2）一定の曲率で湾曲する．（3）湾曲内側軸方 向俚伸びない（4）中閒部分 $L_{m}$ は剖体とする.

図における中心軸湾曲変位 $L_{C}$ 上供給压力 $P$ の関 係は以下の式で与えられる。

$$
\begin{gathered}
L_{C 1}=A P_{1} / K_{1} \\
\\
L_{C 2}=A P_{2} / K_{2}
\end{gathered}
$$

圧力室が加圧されたとき中心軸は一定の曲率で湾 曲すると仮定しているので、幾何学的関係から第一圧 力室と第二圧力室側の自然長 $L_{0}$ はそれぞれ，

$$
\begin{aligned}
& L_{01}=\left(D_{R 1}-D_{g}\right) \alpha_{1} \\
& L_{02}=\left(D_{R 2}-D_{g}\right) \alpha_{2}
\end{aligned}
$$

で与えられ，湾曲時の曲率半径は

$$
\begin{gathered}
D_{R I}=\left(L_{01}+L_{C I}\right) / \alpha_{1} \\
D_{R 2}=\left(L_{02}+L_{C 2}\right) / \alpha_{2}
\end{gathered}
$$

で与えられる.また，指先水平方向変位は，以下の式 で与えられ，

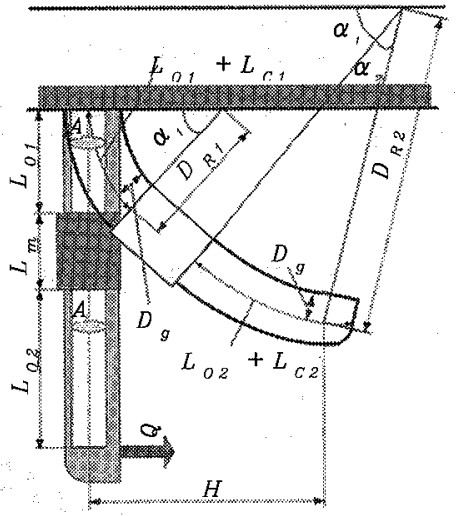

Fig. 8 Analytical model of 2-chamber-type gripper

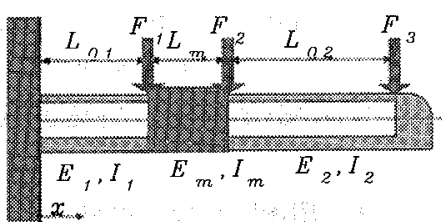

Fig. 9 Cantilever beam with 3 concentrated loads

$$
\begin{aligned}
H= & D_{R 1}\left(1-\cos \alpha_{1}\right)+L_{m} \sin \alpha_{1} \\
& +D_{R 2}\left\{\cos \alpha_{1}-\cos \left(\alpha_{1}+\alpha_{2}\right)\right\}
\end{aligned}
$$

湾曲角 $\alpha$ は十分小さいとして, $\cos \alpha \fallingdotseq 1-\alpha^{2} / 2$, $\sin \alpha=\alpha$ で近似すると，以下の式を得る.

$$
H=\frac{D_{R 1} \alpha_{1}^{2}}{2}+L_{m} \alpha_{1}+\frac{D_{R 2}\left(2 \alpha_{1} \alpha_{2}+\alpha_{2}^{2}\right)}{2}
$$

また，図 9 で示すように，異なる材料で構成される片持ち梁において，3個の集中荷重 $F_{1}, F_{2}, F_{3}$ 考受け る場合について材料力学の重悋合せ法(10)を適用すると，指先水平方向変位 $H$ は次式で表すことができる.

$$
\begin{aligned}
H= & \frac{L_{01}{ }^{2}\left(2 L_{01}+3 L_{m}+3 L_{02}\right)}{6 E_{1} I_{1}} F_{1} \\
+ & \frac{E_{m} I_{m} L_{01}\left\{6 L_{m}\left(L_{01}+L_{m}+L_{02}\right)+L_{01}\left(2 L_{01}+3 L_{02}\right)\right\}+E_{1} I_{1} L_{m}{ }^{2}\left(2 L_{m}+3 L_{02}\right)}{6 E_{1} I_{1} E_{m} I_{m}} F_{2} \\
& +\frac{E_{m} I_{m} E_{2} I_{2} L_{01}\left\{L_{01}{ }^{2}+3\left(L_{01}+L_{m}+L_{02}\right)\left(L_{m 1}+L_{02}\right)\right\}+E_{1} I_{1} E_{2} I_{2} L_{m}\left\{L_{m 1}{ }^{2}+3 L_{02}\left(L_{m}+L_{02}\right)\right\}+E_{1} I_{1} E_{m} I_{m} L_{02}{ }^{3}}{3 E_{1} I_{1} E_{m} I_{m} E_{2} I_{2}} F_{3}
\end{aligned}
$$

さらに, $F_{1}=0, F_{2}=0, F_{3}=Q$ と扔き，中間部は剛体とみなし $E_{m}$ を無限大とすると発生力 $Q$ は次式で 
与えられる.

$$
\left.Q=\frac{3 E_{1} I_{1} E_{2} I_{2}}{E_{1} I_{1} L_{02}^{3}+E_{2} I_{2} L_{01}\left\{L_{01}{ }^{2}+3\left(L_{01}+L_{m}+L_{02}\right)\left(L_{m}+L_{02}\right)\right.}\right\}^{H}
$$

式(1), 式(3), 式(5)より第一圧力室側の湾曲角 $\alpha_{1}$ と 曲率半径 $D_{R 1}$ はそれぞれ，

$$
\begin{aligned}
& \alpha_{1}=A P_{1} / D_{g} K_{1} \cdots \cdots \cdots \cdots \\
& D_{R 1}=\left(L_{01} K_{1}+A P_{1}\right) D_{g} / A P_{1}
\end{aligned}
$$

で与えられ，式(2), 式(4)，式(6)より第二圧力室側の 湾曲角 $\alpha_{2}$ と曲率半径 $D_{R 2}$ はそれぞれ，

$$
\alpha_{2}=A P_{2} / D_{8} K_{2}
$$

式(10)と式(15)をまとめると, 発生力 $Q$ は次式で与えられる.

$$
Q=\frac{3 \frac{E_{1} I_{1}}{K_{1}} \frac{E_{2} I_{2}}{K_{2}} A\left\{\left(L_{01}+2 L_{m}+2 L_{02}\right) P_{1}+\left(\frac{K_{1}}{K_{2}}\right) L_{02} P_{2}\right\}}{2 D_{g}\left[\frac{E_{1} I_{1}}{K_{1}}\left(\frac{K_{1}}{K_{2}}\right) L_{02}^{3}+\frac{E_{2} I_{2}}{K_{2}} L_{01}\left\{L_{01}{ }^{2}+3\left(L_{01}+L_{m}+L_{02}\right)\left(L_{m}+L_{02}\right)\right\}\right]}
$$

で与えられる. 式(8), 式(11)〜式(14)より指先水平方 向変位 $H$ は次式で与えられる. ただし, $L_{01} \gg L_{C, 1}$, $L_{\infty} \gg L_{C 2}$ と近似している.

$$
H=\frac{A P_{1} L_{01}}{2 D_{g} K_{1}}+\frac{A P_{1} L_{m}}{D_{g} K_{1}}+\frac{A P_{1} L_{02}}{D_{g} K_{1}}+\frac{A P_{2} L_{02}}{2 D_{g} K_{2}}
$$

ここで, 一室型である基本グリッパと平型グリッパは, 式(16)において $L_{m}=0, L_{02}=0$ と置いた形，す なわち次式で与えられる.

$$
Q_{1}=\frac{3 E_{1} I_{1} A}{2 D_{g} K_{1} L_{01}^{2}}
$$

指の根元から $x$ の位置における発生力 $Q_{x}$ は次式で与えられる.

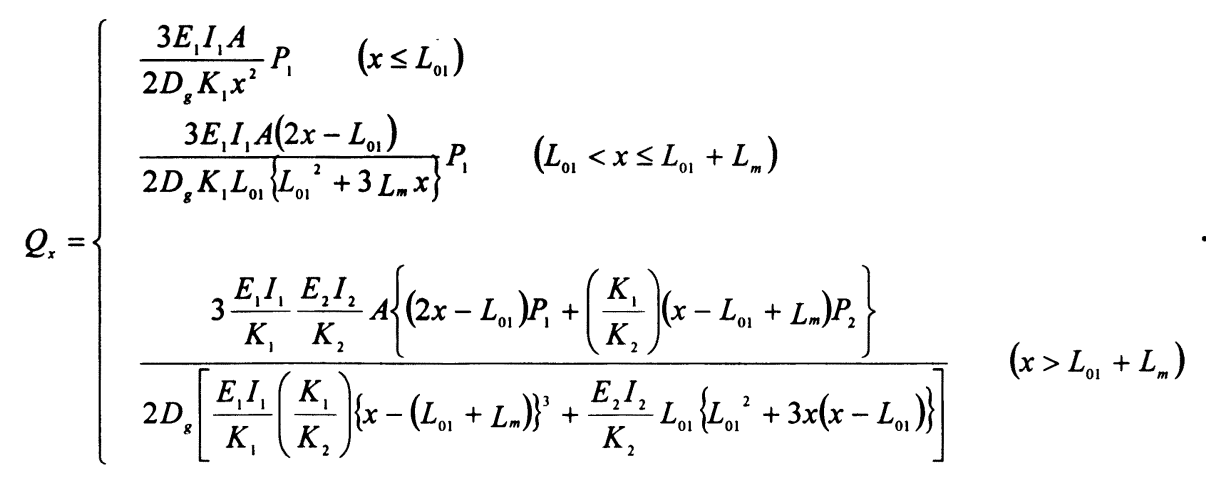




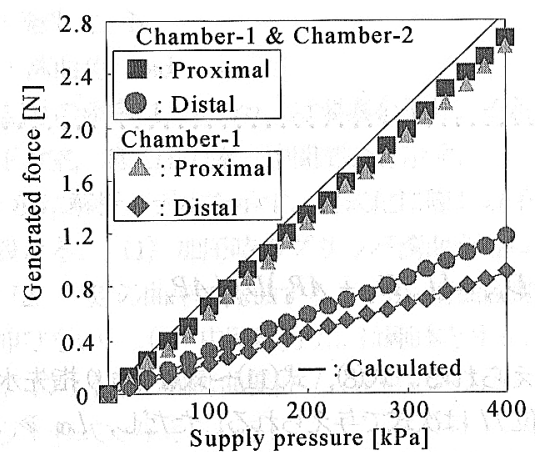

Fig. 10 Relation between supply pressure and generated force of 2-chamber type

$4 \cdot 2$ 突験結果との比較 図 10 に $400 \mathrm{kPa}$ まで 加圧した際の二室型グリッパの供給圧力と発生力の関 係を示す. 図中のりと圆は第一圧力室と第二圧力室を 同時に加圧した際の，それぞれ指の先端部分と中間部 分の発生力を示し，と、注一圧力室のみを加圧し た際の指の先端部分と中間部分の発生力を示している. いずれの場合においても供給圧力の増加とともに発生 力は直線的に増加している. 図中の実線は, 式(16)を 用いて， $E_{1} I_{1} / K_{1}=10.14 \times 10^{7} \mathrm{~m}^{3}, E_{2} I_{2} / K_{2}=8.22 \times 10^{7} \mathrm{~m}^{3}$, $K J K K_{2} \doteqdot 1.0$ として計算した結果である. 図 11 は発生 力の測定位置 $x$ と発生力 $Q_{x}$ の関係を示している. 発 生力は, 測定位置を固定して 2 つの圧力室を同時に $100 \mathrm{kPa}, 200 \mathrm{kPa}, 300 \mathrm{kPa}, 400 \mathrm{kPa}$ と加圧し, 測定し た. 測定位置がグリッパ根元に近い方が発生力が大き くなることがわかる．図中の実線は，式(18)を用いて， $E_{1} I_{1} / K_{1}=10.14 \times 10^{7} \mathrm{~m}^{3}, \quad E_{2} I / K_{2}=8.22 \times 10^{7} \mathrm{~m}^{3}, \quad K_{1} / K_{2}$ $\fallingdotseq 1.0$ として計算した結果である. 図 10 と図 11 にお いて, 計算結果と実験結果はほぼ一致しており，解析 モデルの妥当性が確認できる.

\section{5. 人間型ハント゚への応用}

図 12 にソフトグリッパを用いて試作した人間型五 指ハンドの構造を示寸.このハンドは基本型, 平型, 二室型の三種類のグリッパを用いている. ハンドの寸 法は, 長さ $185 \mathrm{~mm}$, 質量は $250 \mathrm{~g}$ である. 親指用とし て平型グリッパ，小指用として基本グリッパ，その他 の指には二室型グリッパを使用している. また，親指 は内転方向にも動くようになっており，他の指と触れ 合うことができる.すなおち，人間の把握動作に近い 動作が行える構造となっている. また、包努込み把握 (1)を行う際に，五本の指と掌での把握が可能となり， 安定した把握を行える. 図 13 に把握動作時の様子を

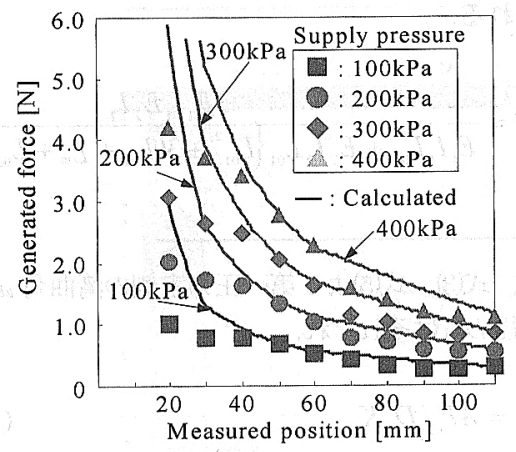

Fig. 11 Relation between measured position and generated fonce

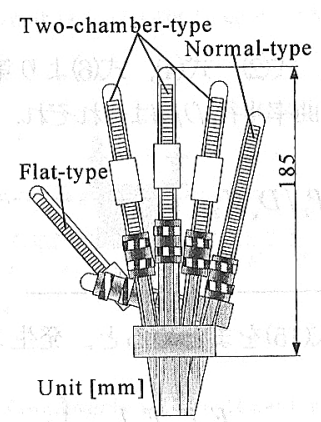

Fig. 12 Structure of 5 -finger hnad
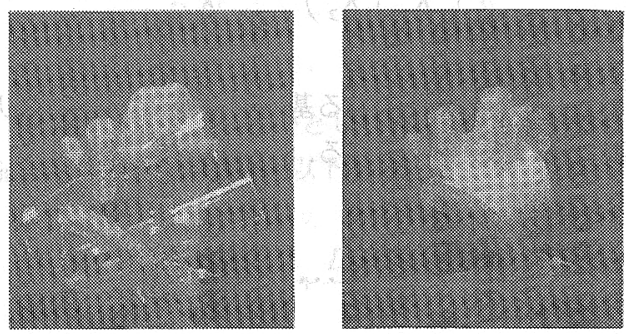

(a). Enveloping grasping
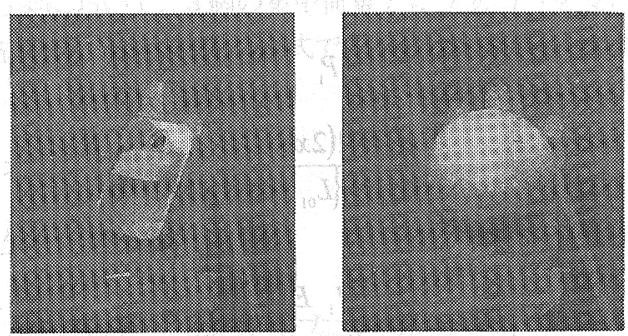

(b). Finger-tip grasping

Fig. 13 Grasping operation 
示す. 図 13 の（a）はそれぞれ高さ $130 \mathrm{~mm}$ 、直径 $90 \mathrm{~mm}$, 質量 $30 \mathrm{~g}$ の円柱 (プラスチックコップ) と直 径 $80 \mathrm{~mm}$, 質量 $5 \mathrm{~g}$ の球体 (発泡スチロール) の包み 込み把握を，図 13 の（b) はそれぞれ高さ $70 \mathrm{~mm}$ ，幅 $40 \mathrm{~mm}$, 厚さ $20 \mathrm{~mm}$, 質量 $15 \mathrm{~g}$ の直方体 (プラスチッ クケース) と直径 $80 \mathrm{~mm}$, 質量 $5 \mathrm{~g}$ の球体 (発泡スチ ロール）の指先把握を示している. これらの写真から， 比較的様々な対象物を上手に把握できることがわかる. なお，図 13 (a) の球体の包み込み把握において，球 体に紐を付けて把持力（引張り力）を測定したところ 最大把持力は $19 \mathrm{~N}$ であった.

\section{6. 結 臬}

シリコーンゴムを用いた三種類の湾曲型空気圧ソ フトアクチュエータを試作し，その特性を調へ，解析 モデルの有効性を検討した. その結果，以下の結論を 得た.

（1） 発生力を増やすためにグリッパの断面形状 を変更した平型ソフトグリッパを試作した．その特性 を調べた結果, 基本グリッパに比べ発生力が約 12 倍 増加した. また, ソフトグリッパの自由度を増やし, 器用な動作を実現させるための二室型ソフトグリッパ を試作した. このグリッパは圧力室を別々に加圧する ことができ，さまざまな動作が可能であることを確認 した. さらに, これらのソフトグリッパを人間型ハン ドに応用し, 平型グリッパはハンドの親指部分に, 二 室型グリッパはその他の指に適用できる可能性を示し た.

(2) グリッパの設計に役立てるためにグリッパ の発生力を計算するための解析モデルを提案した. 計 算結果と実駼結果を比較した結果, 解析モデルの妥当 性を確認した.

ソフトグリッパを細かく制御するためには，グリ ッパの湾曲変位量を検出し，その情報をフィードバッ クする必要がある. 湾曲変位量を検出するセンサとし て, グリッパの特性に影響を与えることなく, グリッ
パに内蔵できる薄くて柔らかいソフトセンサが要求さ れる. 現在, そのような柔軟変位センサを開発中であ り, センサ一体型のソフトアクチュエータを開発する 予定である.

\section{文献}

（1）井上博充・比留川博久, 人間協調・共存型ロボットシステ ム研究開発プロジェクト, 日本ロボット学会誌, 19-1, (2001),2-7.

（2）森田寿郎 - 鈴木雄一郎 - 川崎毅彦 - 管野重樹, 人間共存口 ボットマニピュレータの衝突安全設計, 日本ロボット学会 誌, 16-1,(1998),102-109.

(3) 則次俊郎・角垣一志・堂田周治郎, 空気圧ロボットのコン プライアンスとその制御, 日本ロボット学会誌, 11-2, (1993), 291-298.

（4）鈴森康一, やわらかい機械のための材料技術, 計測と制御, 3-4, (1995), 281-286.

（5）鈴森康一，フレキシブルマイクロアクチュエータに関する 研究(第 1 報, 3 自由度アクチュエータの静特性)機論, 55518, C(1989), 2547-2552.

（6）高森年, アクチュエータ革命，(1987), 99, 工業調査会.

(7) Sasaki, D., Noritsugu, T. ,Takaiwa, M. Development of Pneumatic Soft Hand for Human Friendly, Robot Journal of Robotics and Mechatronics, 15-2, (2003), 164-171.

（8）長田義仁，ソフトアクチュエータ開発の最前線，(2004), 291, エヌ・ティー・エス.

（9）荻島秀雄，カパンディ 関節の生理学 I，(1986)，166，医 歯薬出版.

（10）奥村敦史, 材料力学, (1985)，264，コロナ社

（11）金子真, 包み込み把握, 日本ロボット学会誌, 186, (2000), 24-27. 